\title{
POPULATION STATUS AND DISTRIBUTION OF RHESUS MACAQUE, MACACA MULATTA, IN A MOIST DECIDUOUS FOREST OF BANGLADESH
}

\author{
Habibon Naher*, Shawkat Imam Khan ${ }^{1}$ and Tanvir Ahmed \\ Department of Zoology, Jagannath Unversity, Dhaka 1100, Bngladesh
}

\begin{abstract}
A study was conducted on population status and distribution of Rhesus Macaque, Macaca mulatta, in moist deciduous forest of Bangladesh from April to October 2015. Observation was carried out in the Madhupur deciduous forest, Tangail. In total, 248 individuals belonging to 11 groups were recorded. The group size ranged from 9 to 51 (mean 22.54 \pm 11.68 ) individuals. Among the total population, $48.5 \%$ were adults and $51.5 \%$ immature animals (sub-adult male, sub-adult female, juvenile and infant). The ratio of adult and immature was $1: 1.85$ and the sex ratio of adult male and female was $1: 1.49$. The groups were 0.77 to $7.47 \mathrm{~km}$ (mean $2.5 \mathrm{~km} \pm 2.2, \mathrm{n}=11$ ) apart from each other.
\end{abstract}

Key words: Population, group size, sex ratio, distribution, Rhesus Macaque

\section{INTRODUCTION}

Seven species and 14 subspecies of macaques are known in south Asia (Molur et al. 2003) and five of them occurred in Bangladdesh (IUCN 2000). Except Rhesus Macaque all other macaques (Macaca nemestrina, M. fascicularis, $M$. arctoides and $M$. assamensis) are restricted only in the northeastern and southeastern hill areas of Bangladesh (Hasan et al. 2013). The Rhesus macaques are distributed throughout the country from urban to deep forests (Hasan et al. 2013). They are synanthropic, thriving in human altered environments which help them to be among the most widely distributed and successful primates in the world (Hasan et al. 2013).

Primate populations are being reduced or eliminated in many parts of the world due to habitat destruction, competition for food and space, bushmeat hunting, biomedical research and the pet trade (Wolfheim 1983). The Madhupur forest is highly fragmented and disturbed forest in Bangladesh. It is under high pressure for fuel wood, fallen dry leaves for cooking, grazing, illicit felling and fire hazards (Khan 2010). In winter, some areas of the park are cleared up by the cultivators and utilized for growing various crops (Khan 2010). The forests are being destroyed at an unprecedented rate to clear land for pineapple (Ananus comosus), banana (Musa spp.) and kachu (Colocasia spp.) cultivations and human settlement (Khan 2010). Large number of human population (about

*Corresponding author: likhi.habibon@gmail.com, ${ }^{1}$ Department of Natural History, Bangladesh National Museum, Shahbag, Dhaka-1000, Bangladesh.

(C) 2016 Zoological Society of Bangladesh DOI: 10.3329/bjz.v44i1.30177 
$60,000)$ of this area, with its increasing need for fuel wood, timber, building material and cultivable land exert heavy pressure on the remaining forest area (Hossain et al. 2004). On the other hand, natural Shal stock has lost its vigorous coppicing ability to a great extent, bole becomes malformed, and the growth of the trees seems to be stunted (Hossain et al. 2004). A recent estimate reveals that over $70 \%$ of the Shal forest area is either degraded or encroached by this time (Nishat et al. 2002). Thus the most important underlying causes of this destruction are high population pressure and weak forest management system. Several researchers worked on distribution and population composition of Rhesus Macaques in Bangladesh (Green 1978, Gittins 1980, Khan and Ahsan 1981, Feeroz et al. 1995, Feeroz 2001, Hasan et al. 2013, Sultana 2012). The present study aims to describe the current population status and distribution of Rhesus Macaque, Macaca mulatta, in Madhupur foreset. The objectives of this study were to find out the total population of the Rhesus Macaques in this deciduous forest, total no of groups mentioning their group size and composition and distribution of Rhesus Macaques in the Madhupur forest of Bangladesh.

\section{MATERIAL AND METHODS}

The study was carried out in the Madhupur deciduous forest, Tangail, during April to October 2015. The Madhupur forest is the largest deciduous forest $(24,150$ ha) of Bangladesh. It is situated in the northern part of BhawalMadhupur Shal (Shorea robusta) forest tract, somewhat $50 \mathrm{~km}$ south of the Garo Hills of the Meghalaya State of India, and $110 \mathrm{~km}$ north of Dhaka, the capital of Bangladesh. Geographically, it lies in $24^{\circ}$ to $25^{\circ} 15^{\prime} \mathrm{N}$ latitudes and $90^{\circ}$ to $91^{\circ} \mathrm{E}$ longitudes. The forest is partly dense and partly thin including some scrub jungles and human settlements. There are numerous depressions with gentle slope intercepting the ridges. In general, the Madhupur forest is dominated by Shal (Shorea robusta) trees associated with other tree species like Gramboroi (Zizyphus oenoplea), Amla (Phyllanthus embelica), Bahera (Terminalia belerica) etc. The shrub consists of species like Mach (Leea crispa), Matkila (Glycosmis pentaphylla), Bankarpas (Thespesia lampus) and Atlera (Urena lobata). It also sustains some climbers such as Alkushi (Mucuna pruiens), Parkath (Ficus scandens), Sunat (Pothos scandens) and Bulkumia (Smilax macrophylla), and herbs like Ochunti (Ageratum conyzoides), Salpani (Desmodium gangeticum), Hurhuria (Cleome viscosa), and Bhant (Clerodendrum viscosum) are also present. In total 176 vascular plant species was recorded by Rosario (1997a, b) from the Madhupur National Park. Madhupur forest areas are under the administrative control of Tangail (includes 4 ranges) and Mymensingh (include 1 range) Forest Divisions. Formerly, the forests were managed under coppice systems with a rotation of 25 years (Das 1982). Areas where Shal trees were comparatively less 
were managed through clear felling system followed by artificial regeneration mostly with Shal and other suitable species (White and Ali 1979, Das 1982, Mohiuddin 1982). The total Madhupur area is divided into 5 Ranges and 10 Beats for the management of the forest.

In Madhupur forest, the climate is moderate. Warm weather spread over March to October, maximum temperature was $34.8^{\circ} \mathrm{C}$ in April and the minimum was $13.3^{\circ} \mathrm{C}$ in February. The highest rainfall recorded in July and the lowest in March.

A total of 36 days, 432 hours were spent to carry out research at the forest area. Fortnightly two days long survey was done. To find out the group number, group size and group composition line transect method (Brockelman and Ali 1987) was used to cover all areas in the forest. Repeat surveys were conducted recording group size and structure, age and sex ratio. Surveys were carried out from dawn to dusk. The species were classified into four age categories; adult, sub-adult, juvenile and infant based on the morphological differences described by Stanford (1991). Sex identification was difficult in juveniles and had chances to be wrong, thus sex data weren't collected for juveniles. Groups were separated from each other investigating their location of occurrences, group size and group compositions. Double-counting was avoided by identifying social groups; comparing group size, composition and visible markings of members (injury, abnormalities or other characteristic morphology) mentioned by Hasan et al. (2013). GPS coordinates were noted whenever any group of Rhesus Macaque was found.

\section{RESULTS AND DISCUSSION}

Altogether, 248 individuals of 11 troops of Rhesus Macaque were recorded in the study area (Table 1). More than half of the population $(54.5 \%)$ was recorded in Dokhola (22.6\%), Santoshpur (20.6\%) and Jaloi Cottage of Beribaid (11.3\%) area (Fig. 1). In Santoshpur, only one troop with the largest group size (51 individuals) and in Jaloi Cottage only one group (28 individuals) and Dokhola beat two groups (one with 25 and another with 31 individuals) were recorded. These three areas were less dense with scattered tall trees and fragmented canopies. Visitors and tourists visited the area frequently and supplied banana, biscuits, bread and nut all day long. As a result large numbers of macaques congregated there due to availability of foods. Moreover, the Border Guard Bangladesh (BGB) provides 3 sacs rice to Union Parishad Chairman repeatedly after 3 months in Santoshpur and they supplied rice directly or after boiling. On 


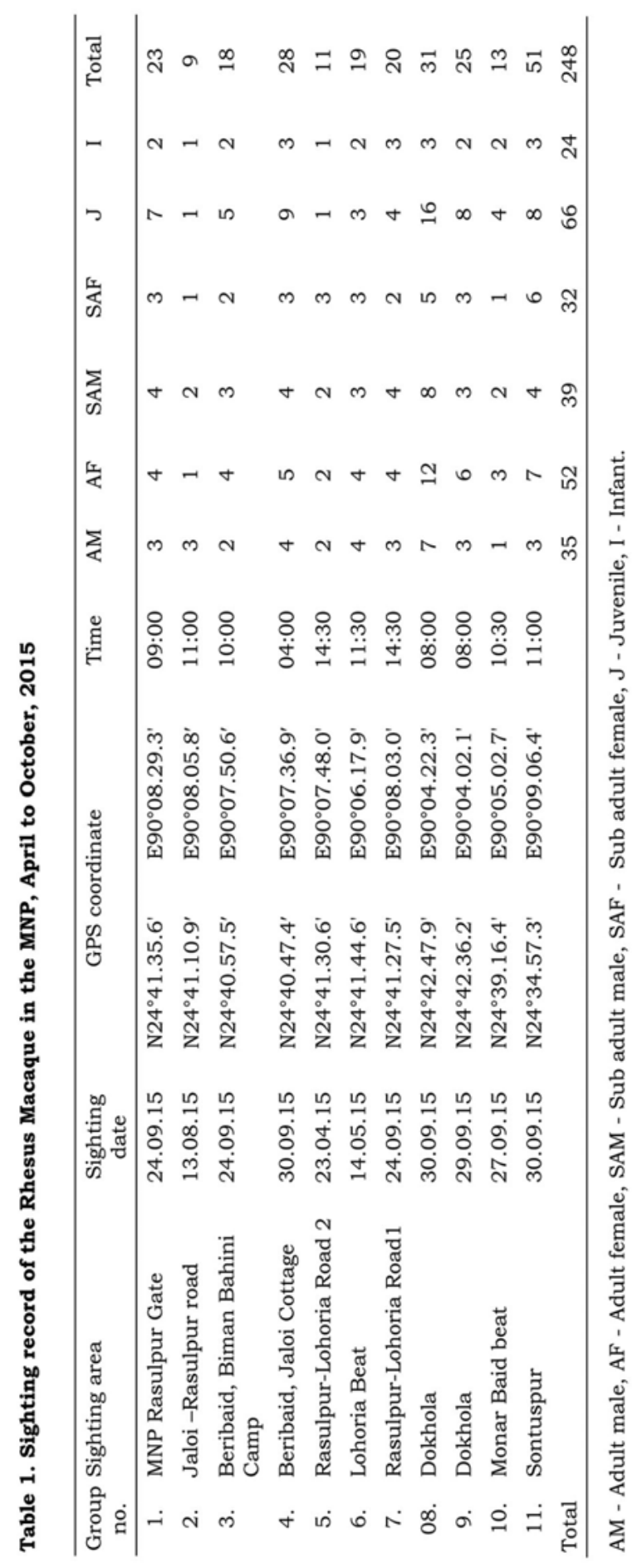


the other hand, the forest guard in the department of Forest of Bangladesh supplied one dozen banana, 10 - 12 packet bread (100 g per packet), 2 packet toast biscuits, $200 \mathrm{~g}$ nut and $2 \mathrm{~kg}$ rice at morning and afternoon at the premises of Joloi cottage in Beribaid beat of Madhupur National forest.

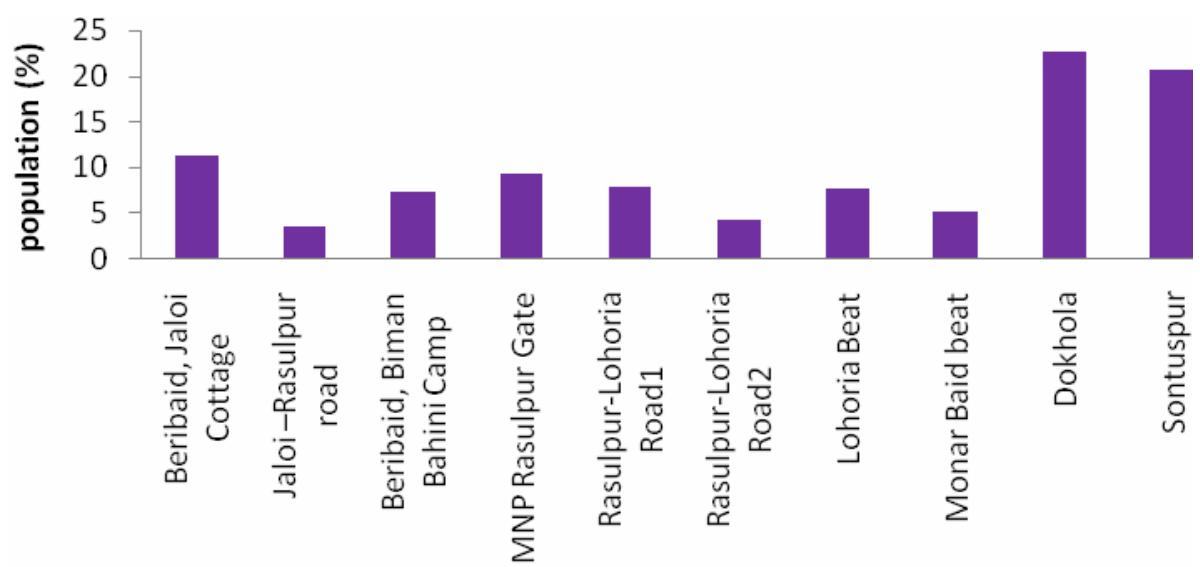

Sighting area

Fig. 1. Population of RM in different locations of Madhupur forest.

The group size ranged from 9 to 51 (Fig. 2) whereas the average was $22.54 \pm$ 11.68 individuals. It is already mentioned that the group sizes were comparatively larger in those areas where provisioned foods were available. Thus, it might be mentioned that the Rhesus Macaque was available on the basis of availability of ready foods rather than natural foods. They preferred to live in at the periphery of the forest where visitors were regularly traveling, as the visitors enjoyed supplying food and took photo and played with the macaques.

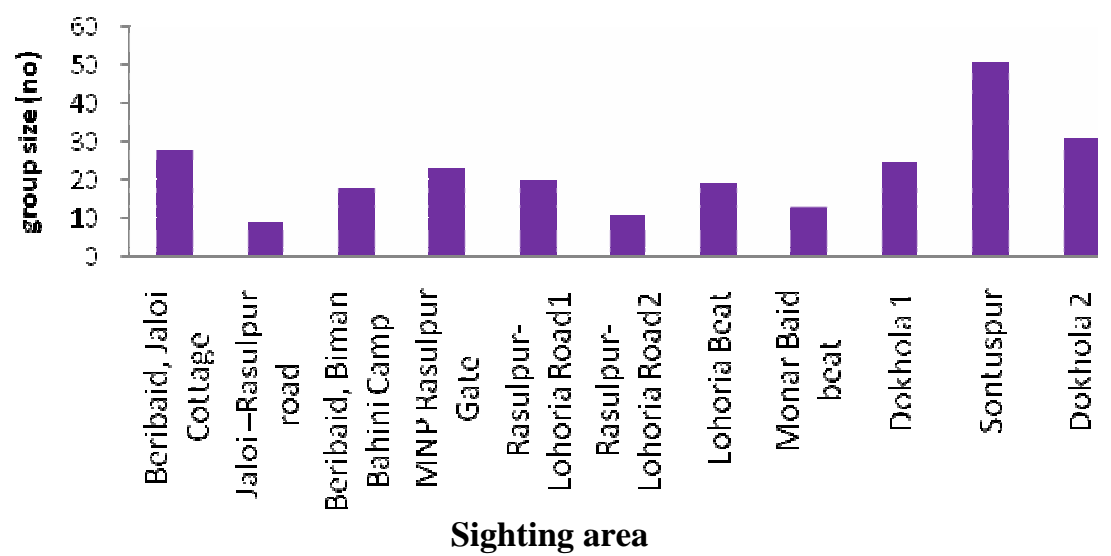

Fig. 2. Group size of RM in different troops of different locations in Madhupur forest. 
Group composition: Among the 248 individuals of Rhesus Macaque, 35.08\% were adult individual, of which $40.2 \%$ were adult male and $59.8 \%$ were adult female (Fig. 3). The immature (sub-adult, juvenile and infant) comprised $64.92 \%$ of the total population. The mean ratio of the adult and immature was 1:1.85 (Table 2).

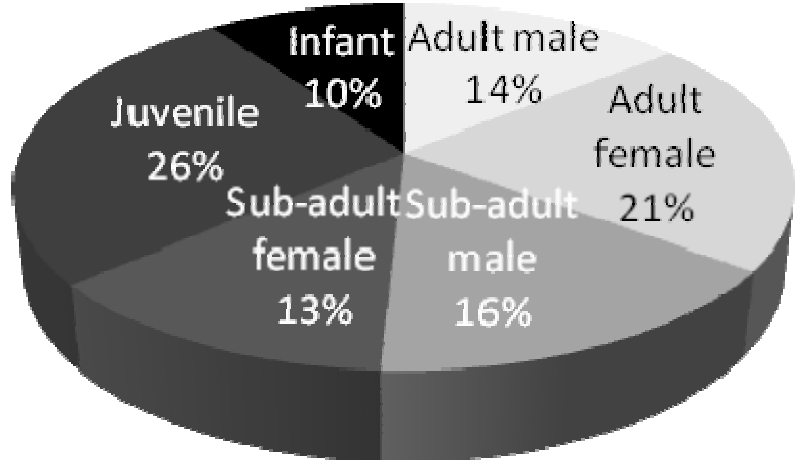

Fig. 3. Age-sex composition of Rhesus Macaque.

Group structure: Different types of social structures found in the troops of Rhesus Macaque. During this study mostly multi-male multi-female (81.8\%) social structures were recorded. Single-male multi-female (18.2\%) structures were also recorded for a limited troop (Table 2).

Table 2. Age-sex ratio of the Rhesus Macaque in the MNP, April to October, 2015

\begin{tabular}{|c|c|c|c|c|c|c|c|c|}
\hline $\begin{array}{l}\text { Group } \\
\text { No. }\end{array}$ & Sighting area & $\mathrm{AM}$ & $\mathrm{AF}$ & AM:AF & Adult & Immature* & $\begin{array}{l}\text { Adult : } \\
\text { Immature }\end{array}$ & Total \\
\hline 1. & Rasulpur Gate & 3 & 4 & $1: 1.3$ & 7 & 16 & $1: 2.28$ & 23 \\
\hline 2. & Beribaid-Rasulpur road & 1 & 3 & $1: 3$ & 4 & 5 & $1: 1.25$ & 9 \\
\hline 3. & $\begin{array}{l}\text { Beribaid, Biman Bahini } \\
\text { Camp }\end{array}$ & 2 & 4 & $1: 2$ & 6 & 12 & $1: 2$ & 18 \\
\hline 4. & $\begin{array}{l}\text { Beribaid, Jaloi Cottage } \\
\text { (North) }\end{array}$ & 4 & 5 & $1: 1.3$ & 9 & 19 & $1: 2.11$ & 28 \\
\hline 5. & Rasulpur-Lohoria Road & 2 & 2 & $1: 1$ & 4 & 7 & $1: 1.75$ & 11 \\
\hline 6. & Lohoria Beat & 4 & 4 & $1: 1$ & 8 & 11 & $1: 1.4$ & 19 \\
\hline 7. & Rasulpur-Lohoria Road & 3 & 4 & $1: 1.3$ & 7 & 13 & $1: 1.85$ & 20 \\
\hline 8. & Sontuspur & 7 & 12 & $1: 1.7$ & 19 & 32 & $1: 1.7$ & 31 \\
\hline 9. & Dokhola & 3 & 6 & $1: 2$ & 9 & 16 & $1: 1.8$ & 25 \\
\hline 10. & Monar Baid beat & 1 & 3 & $1: 3$ & 4 & 9 & $1: 2.25$ & 13 \\
\hline 11. & Dokhola & 3 & 7 & $1: 2.3$ & 10 & 21 & $1: 2.1$ & 51 \\
\hline Total & & 35 & 52 & & 87 & 161 & & 248 \\
\hline Mean & & & & $1: 1.49$ & & & $1: 1.85$ & \\
\hline
\end{tabular}

*Immature $=$ Sub-adult male, sub-adult female, juvenile and infant. 
Sex composition: The ratio of adult male and female was $1: 1.49$ (Table 2). Most of the troops (36.3\%) had $1: 1.3$ adult male and female sex ratios (Fig. 4). Only one troop had multi males and single female structure whose sex ratio was $3: 1$.

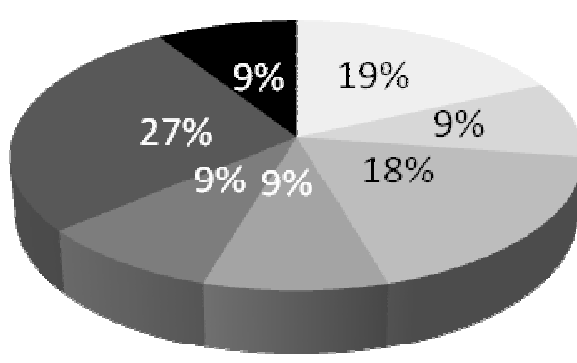

$$
\begin{aligned}
& 1 \text { male: } 1 \text { female } \\
& 1 \text { male: } 1.7 \text { females } \\
& 1 \text { male: } 1.2 \text { females } \\
& 1 \text { male: } 1.23 \text { females } \\
& 1 \text { male: } 1.25 \text { females } \\
& 1 \text { male: } 1.3 \text { remales } \\
& -1 \text { male: } 3 \text { females }
\end{aligned}
$$

Fig. 4. Ratio of adult male and female in Rhesus Macaque.

Distribution of Rhesus Macaque among the forest area: Rhesus Macaque was widely distributed in the forest (Fig. 5). The lowest distance $(0.77 \mathrm{~km})$ was recorded between groups nos. 3 and 4 whereas the highest distance $(7.47 \mathrm{~km})$ was between 9 and 10. Meanwhile, group no. $6(4.23 \mathrm{~km})$ and $7(3.76 \mathrm{~km})$ were closer to group no 9 and group no. 11 (Fig. 6). The mean distance was $2.5 \mathrm{~km} \pm$ $2.2(\mathrm{n}=11)$. During the study period it was recorded that the Rhesus Macaque foraged from forest floor to top canopy. But they preferred to live in less dense forest and at the periphery of the forest where visitors were regularly traveling and supplied food for recreation.

In Madhupur deciduous forest, altogether 248 individuals of 11 groups were recorded but Hasan et al. (2013) recorded 347 individuals of 18 groups in Bhawal and Madhupur deciduous forest of Bangladesh. The group size was bigger in the place where visitors and tourists come and provided foods for recreation. The highest group size (51 individuals) was recorded in Santoshpur of Madhupur deciduous forest where large number of visitors regularly visited the area to observe the macaques and provided food for enjoyment. Chopra et al. (2013) recorded 20 to 56 individuals in Haryana of India. Troops may number in the hundreds in mountain regions and areas of high human food subsidization or agricultural habitats (Seth and Seth 1983, Seth et al. 1992, Southwick and Siddiqui 2001). Troop size was comparatively larger near human habitations than the forested areas (Chopra et al. 2013). The group size is larger (range 22 - 
90 , mean $41.3 \pm 16.7, \mathrm{n}=37$ ) in urban area than found in the forested area (range $10-78$, mean $30.2 \pm 10.9, \mathrm{n}=176$ ) because of food availablity (Hasan et al. 2013). Environmental constraints and human interference might affect composition and group size of the macaques (Machairas et al. 2003). The size and composition of social groups varies geographically (Chivers and Raemakers

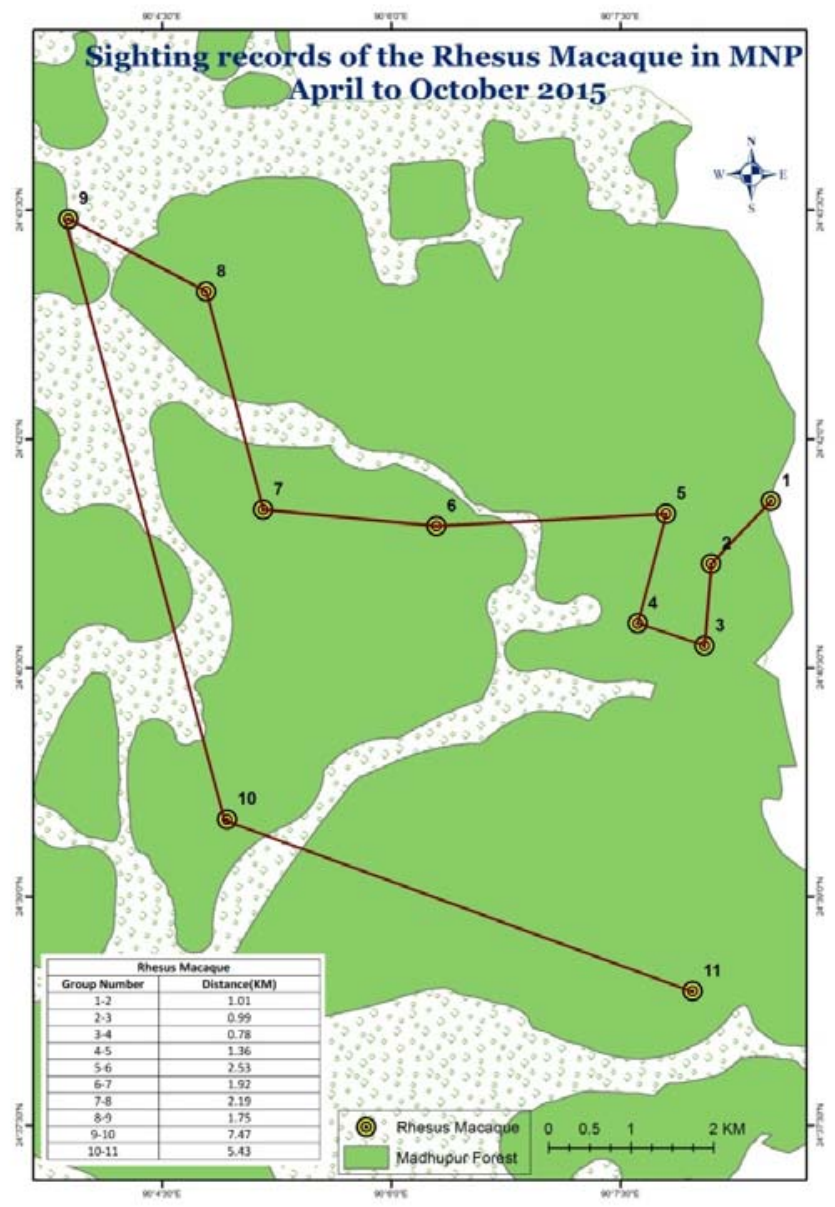

Fig. 5. Distribution and distance between groups of Rhesus Macaque in Madhupur forest.

1980) because of habitat structure and food availability (Kumar and Solanki 2008). The mean group size was quite larger (22.54 \pm 11.68 individuals) than the earlier record (19.3 \pm 5.5 individuals) in central (Bhawal and Modhupur) deciduous forest of Bangladesh (Hasan et al. 2013) and in Haryana (average 40.6 individuals) of India (Chopra et al. 2013). It has already mentioned that the largest population and the largest group size depended on the human subsidized food which was also reported by Chopra et al. (2013) in Haryana of India and Hasan (2010) in Charmuguria of Bangladesh. However, group size and 
population may increase very quickly due to provisioning food by the government, local inhabitants and visitors. Thus, the population growth rate is higher in urban areas than in the forested areas (Hasan et al. 2013). It also found that in the study area the Rhesus Macaques were very well adapted to human presence and they frequently raided to crops, human settlements, vegetable gardens, agricultural land, shops and fruit garden. Chopra et al. (2013) also recorded about their raid to crops, human settlements, vegetable shop and temples. Therefore, abundance, distribution and quality of food affect group size (Wrangham 1980, Mehlman 1989, Menard and Vallet 1997, Kumar and Solanki 2008). Animals will choose to live in those places where they will have the maximum chance of survival or reproductive success (Partridge 1978).

In the present study, the adult male and female was 14.11 and $20.97 \%$ respectively whereas it was 11 and $21 \%$, respectively in urban areas (Hasan et al. 2013, Jaman and Huffman 2013). The immature (sub-adult, juvenile and infant) comprised $64.92 \%$ of the population in the study area but in urban areas it was $68 \%$ (op. cit.). In the present study, the mean ratio of the adult and nonadult was lesser $(1: 1.85)$ than the ratio $(1: 1.93)$ recorded in Bhawal and Madhupur deciduous forest earlier (op. cit.).

In the study period, in association with multi-male multi-female social structures $(81.8 \%)$, single male single female and multi male single female structures were also recorded but Chopra et al. (2013) found multi-male multi female types only in Haryana of India.

The sex ratio varied group to group and area to area. Chopra et al. (2013) also reported that among non-human primates the sex ratio varies greatly from habitat to habitat and year to year. The adult male number in the present study ranged from 1 to 7 individual whereas the female ranged from 1 to 12 . Thus, the mean adult sex ratio $(1: 1.49)$ was lesser than the earlier record $(1: 2.56)$ in Bhawal and Madhupur deciduous forest (Hasan et al. 2013) and Haryana of India (1: 1.26) (Chopra et al. 2013).

The Rhesus Macaque was widely distributed in the forest area from deep forest to peripheral region. RM foraged on the forest floor, sometimes foraged on tree top of preferred food plants (Mangifera indica, Litchi chinensis, Artocarpus heterophyllus). The availability of food trees may be a limiting factor (Joseph and Ramachandran 2003).

The group of Rhesus Macaque was 0.78 to $5.43 \mathrm{~km}$ apart from each other. Hasan et al. (2013) reported that the populations were geographically isolated from each other by 30 to $300 \mathrm{~km}$ apart in urban areas of Bangladesh. In Madhupur National Park, groups were located less than $10 \mathrm{~km}$ apart from each other they were considered to form a single population (op. cit.). Research at Lawachhara National Park (Feeroz 1991) indicates that a group can range over 5 
$\mathrm{km}^{2}$ and adult males in the population can move about $10 \mathrm{~km}$ in three days, which indicates that adult males may travel $20 \mathrm{~km}$ even in a fragmented habitat. Hanya et al. (2003) stated that a 'group' should be modified to reflect the normal group spread of the species and defined a group only by distance and did not distinguish situation when macaques belonging to different social units (troop) stayed within $500 \mathrm{~m}$ each other. Distribution of species in different habitats may not follow directly from habitat preference or choice; inter and intraspecific competition can exclude animals from preferred habitats and force them into less suitable areas (Partridge 1978). Koganezawa (1995) considered $15 \mathrm{~km}$ as the separator distance between the two populations of Japanese Macaque, while several studies recorded male migration of more than $45 \mathrm{~km}$ in this species (Yoshimi and Takasaki 2003). Population genetic studies of Japanese macaques suggest that groups geographically separated by more than $100 \mathrm{~km}$ are genetically distinct from each other (Nozawa et al. 1996). However, from ecological point of view, several factors may affect male migration, including geographical barriers such as large rivers, large human settlements and discontinuous habitat (Hasan et al. 2013).

Acknowledgements: The authors would like to express gratitude to the Ministry of Science and Technology (MOST), Government of the People's Republic of Bangladesh, for providing financial support for this study. The authors thank the Ministry of Environment and Forest, Bangladesh for giving permission to conduct this study in Madhupur National Park. They are also thankful to Mr. Johni Miah, M. Sc. student, Dept. of Geography, Jagannath University for preparing the GIS map.

\section{LITERATURE CITED}

BROCKELMAN, W.Y. and ALI, R. 1987. Methods of surveying and sampling forest primate populations. In: Primate Conservation in the Tropical Forest, C. W. Marsh and R. A. Mittermeier (eds.), Alan R. Liss, New York. pp. 23-62.

CHIVERS, D.J. and RAEMAEKERS, J.J. 1980. Long-term changes in behaviour. In: Malayan Forest Primates: Ten Years' Study in Tropical Rain Forest, D.J. Chivers (ed.), Plenum Press, New York. pp. 209-260.

CHOPRA G. BHOOMBAK and KUMAR, P. 2013. Prevalence of non-human primates in Morni Hills of Haryana, India: A survey. Tigerpaper 40(2): 1-9.

DAS, S 1982. The forest management practice in Bangladesh. Proceedings of the Second Bangladesh National Conference on Forestry. Dhaka. pp. 6-18.

FEEROZ, M.M. 1991. Ecology and Behaviour of Hoolock Gibbon Hylobates hoolock of Bangladesh. M.Sc. thesis, Jahangirnagar University, Bangladesh.

FEEROZ, M.M. 2001. Species diversity and population density of non-human primates in north-east and south-east of Bangladesh. Ecoprint 8(1): 53-57.

FEEROZ, M.M., ISLAM, M.A. and KABIR, M.M. 1995. Status, distribution and conservation of nonhuman primates of Bangladesh. Kyoto Univ. Overseas Research Report of Studies on Asian Non-human Primates 9: 73-82. 
GITTINS, S.P. 1980. A Survey of the Primates of Bangladesh. Project Report to the Forest Department of Bangladesh, Dhaka.

GREEN, K.M. 1978. Primates of Bangladesh: a preliminary survey of population and habitat. Biological Conservation 13: 11-160.

HANYA, G., YOSHIHIRO, S., ZAMMA, K., KUBO, R., and TAKAHATA, Y. 2003. New Method to Census Primates Groups: Estimating Group Density of Japanese Macaques by Point Census. American Journal of Primatology 60: 43-56.

HASAN, M.K. 2010. Population Organization and Genetic Variation of Rhesus Macaque (Macaca mulatta) Living in Urban Areas of Bangladesh. M.Phil. thesis, Department of Zoology, Jahangirnagar University, Savar, Dhaka, Bangladesh.

HASAN, K., AZIZ M. A, ALAM S.M.R., KAWAMOTO Y., LISA JONES-ENGEL, KYES R.C., AKHTAR S., BEGUM S. and FEEROZ M.M. 2013. Distribution of Rhesus Macaques (Macaca mulatta) in Bangladesh: Interpopulation Variation in Group Size and Composition. Primate Conservation 26(1): 125-132.

HOSSAIN, M.K., MIAH, M.D. and MUHAMMED, N. 2004. Conservation of natural Sal forests to short rotation forests with alien species in Bangladesh-Madhupur Sal forests perspectives. Journal of Forestry and Environment 2: 7-17.

IUCN, BANGLADESH. 2000. Red book of threatened mammals of Bangladesh. IUCN-The World Conservation Union. xii+71 pp.

JAMAN, M.F. AND HUFFMAN, M.A. 2013. The effect of urban and rural habitats and resource type on activity budgets of commensal rhesus macaques (Macaca mulatta) in Bangladesh. Primates 54: 49-59.

JOSEPH, G.K. and RAMACHANDRAN, K.K. 2003. Distribution and demography of the Nilgiri langur (Trachypithecus johnii) in Silent Valley National Park and adjacent areas, Kerala, India. Primate Conservation 19: 78-82.

KHAN, S.I. 2010. Frugivorous Birds and Seed Dispersal in Madhupur National Park and Chittagong University Campus, Bangladesh. Unpublished M.Phil. Thesis. Department of Zoology, University of Chittagong. xi+209 pp.

KHAN, M.A.R. and AHSAN, F. 1981. The group structure, composition and age-sex relationship of primates in Bangladesh. Proceedings of the 3rd National Zoological Conference, Bangladesh. pp. 287-302.

KOGANEZAWA, M. 1995. Extraction and isolation degree of the local population of Japanese monkeys using Geographic Information System. Primate Reserve 11(2): 67-81.

KUMAR, A. and SOLANKI, G.S. 2008. Population status and conservation of Capped Langurs (Trachypithecus pileatus) in and around Pakke Wildlife Sanctuary, Arunachal Pradesh, India. Primate Conservation 16(1): 107-113.

MACHAIRAS, I., CAMPERIO, C.A. and SGARDELIS, S. 2003. Interpopulation differences in activity patterns of Macaca sylvanus in the Moroccan Middle Atlas. Human Evolution 18(3-4): 185-202.

MEHLMAN, P.T. 1989. Comparative Density, Demography, and Ranging Behavior of Barbary Macaques (Macaca sylvanus) in Marginal and Prime Conifer Habitats. International Journal of Primatology 10(4): 269-292.

MENARD, N. and VALLET, D. 1997. Behavioural Responses of Barbary macaques (Macaca sylvanus) to Variations in Environmental Conditions in Algeria. American Journal of Primatology 43: 285-304. 
MOHIUDDIN, S. 1982. Management practices of Sal forest of Bangladesh. Proceeding of the Second National Conference on Forestry. Dhaka, Bangladesh. pp. 55-57.

MOLUR, S., BRANDON-JONES, D., DITTUS, W., EUDEY, A., KUMAR, A., SINGH, M., FEEROZ, M.M., CHALISE, M., PRIYA, P. and WALKER, S. 2003. Status of South Asian Primates: Conservation Assessment and Managment Plan Report. Workshop Report, 2003. Zoo Outreach Organization/CBSG-South Asia, Coimbatore, India.

NISHAT, A., HUQ, S.M.I., BARUA, S.P., REZA, A.H.M.A. and Khan, A.S.M. 2002. Bio-ecological Zones of Bangladesh. IUCN Bangladesh Country Office, Dhaka, Bangladesh. xii+141 pp.

NOZAWA, K., SHOTAKE, T., MINEZAWA, M., KAWAMOTO, Y., HAYASAKA, K. and KAWAMOTO, S. 1996. Population genetic studies of the Japanese macaque Macaca fuscata. In: Variations in the Asian Macaques, T. Shotake and K. Wada (eds.). Tokai University Press, Tokyo. pp. 1-36.

PARTRIDGE, L. 1978. Habitat selection. In Behavioral Ecology (eds J.R. Krebs \& N.B. Davies), Blackwell Scientific, Oxford.

ROSARIO, E.A. 1997a. The Conservation Management Plan of the Wildlife Sanctuaries in the Sundarbans Forests. Mandala Agricultural Development Corporation, Dhaka.

ROSARIO, E.A. 1997b. The Conservation Management Plan of the Protected Areas Other Than Those in the Sundarbans Forests in Bangladesh. Mandala Agricultural Development Corporation, Dhaka.

SETH, P.K. and SETH, S. 1983. Brief report: Population dynamics of free-ranging Rhesus Monkey in different ecological conditions in India. American Journal of Primatology 5(1): 61-67.

SETH, P. K., SETH, S., REDDY, C.L. and CHOPRA, P.K. 1992. Population trends in naturally occurring Rhesus Monkey populations in different habitats in India. Primate Report 32: 61-73.

SOUTHWICK, C.H. and SIDDIQI, M.E. 2001. Status, conservation and management of primates in India. ENVIS Bulletin: Widlife and Protected areas. 1(1): 81-91.

SULTANA, R. 2012. Status and distribution of Rhesus Macaque Macaca mulata in Metropolitan Dhaka City. J. Asiatic Soc. Bangladesh (Sci.) 38(2): 175-181.

STANFORD, C.B. 1991. The capped langur in Bangladesh: behavioral ecology and reproductive tactics. Contrib. Primatology 26: 1-179.

WHITE, K.J. and ALI, M.O. 1979. Research Objectives. Field Document No. 2. Bangladesh Forest Research Institute, Chittagong, Bangladesh. pp. 1-88.

WOLFHEIM, J.H. 1983. Primates of the World: Distribution, Abundance, and Conservation. University of Washington Press, Seattle, WA.

WRANGHAM, R.W. 1980. An Ecological model of female-bonded Primate group. Behaviour 75: 261-300.

YOSHIMI, I. and TAKASAKI, H. 2003. Long distance mobility of male Japanese macaques evidenced by mitochondrial DNA. Primates 44: 71-74.

(Manuscript received on 10 January, 2016; revised on 08 May, 2016) 